\title{
Analysis of a Monitoring System for Bacterial Wilt Management by Seed Potato Cooperatives in Ethiopia: Challenges and Future Directions
}

\author{
Shiferaw Tafesse ${ }^{1,2,3, *}$, Rico Lie $^{2}{ }^{\circledR}$, Barbara van Mierlo $^{2}{ }^{\oplus}$, Paul C. Struik ${ }^{1}$, Berga Lemaga $^{3}$ \\ and Cees Leeuwis ${ }^{2}$ \\ 1 Centre for Crop Systems Analysis, Wageningen University, PO Box 430, 6700 AK Wageningen, The Netherlands; \\ paul.struik@wur.nl \\ 2 Knowledge, Technology and Innovation Group, Wageningen University, PO Box 8130, \\ 6700 EW Wageningen, The Netherlands; rico.lie@wur.nl (R.L.); barbara.vanmierlo@wur.nl (B.v.M.); \\ cees.leeuwis@wur.nl (C.L.) \\ 3 CGIAR Research Program on Roots, Tubers and Bananas (RTB), International Potato Center (CIP), \\ PO Box ILRI c\o CIP 5689, Addis Ababa, Ethiopia; B.Lemaga@cgiar.org \\ * Correspondence: shiferawtafesse.gobena@wur.nl
}

Received: 22 February 2020; Accepted: 24 April 2020; Published: 28 April 2020

\begin{abstract}
Collective action is required to deal with various complex agricultural problems such as invasive weeds and plant diseases that pose a collective risk to farmers. Monitoring systems could help to stimulate collective action and avoid free-riding. The paper develops a novel framework consisting of essential elements of a monitoring system for managing a complex disease like bacterial wilt in potato crops. The framework is used to explore how seed potato cooperatives in Ethiopia operationalised the essential elements of a monitoring system and identifies which challenges remain to be overcome. Data were collected through in-depth interviews, reflective workshops, participant observation, and document analysis. We found that the cooperatives had organised a self-monitoring system to monitor disease occurrence and the disease management practices of their members. Monitoring committees were in charge of the data collection and enforcement of sanctions on farmers who did not adhere to the cooperatives' bylaws. The main challenges included the dependency on visual observation, which does not disclose latent infections, limited financial incentives for the monitoring committee members, lack of trust, weak peer monitoring, and the social and ecological interdependency between producers of ware and seed potatoes. Suggestions are provided to strengthen the monitoring systems of farmers' seed potato cooperatives in Ethiopia. In addition, we discuss the broader value of our novel framework for describing and analysing monitoring systems for future research and intervention.
\end{abstract}

Keywords: collective action; monitoring system; seed cooperatives; bacterial wilt; disease management

\section{Introduction}

Potato (Solanum tuberosum L.) is the third most important consumed crop in the world, playing a vital role in food and nutrition security in many countries [1]. Particularly, in the face of the rising global population, the role of this crop is significant in enhancing food supply. However, due to biotic and abiotic conditions, the actual yield of potato is much lower than its potential yield. According to a recent study by Haverkort and Struik [2], there is a gap of $10 \%$ to $75 \%$ between the actual and potential yield of potato due to various socio-ecological problems. In East Africa, where the livelihood of millions of smallholder farmers depends on potato, poor quality seed and bacterial wilt have been identified as 
main yield gap drivers [3]. Reducing the yield gap due to complex socio-ecological problems such as bacterial wilt can therefore improve the livelihood of millions of smallholder farmers.

In cognizance of the potential of potato for food and nutrition security, Ethiopia has been expanding potato production [4-7]. Annual potato crop production is currently valued at more than USD 1.16 billion, and over 3.7 million smallholder farmers are growing the crop in the country $[4,8]$. To enhance quality seed potato availability in the country, hundreds of seed potato cooperatives have been established during the last decade [9-12]. The seed potato cooperatives have been able to enhance seed availability in the country [9,12]. For instance, according to Sisay et al. [12], more than $20 \%$ of the national seed potato demand was supplied by seed potato cooperatives in Ethiopia. Despite the improvement in the availability of seed potato, poor seed quality has remained a major constraint $[10,13]$. The use of poor quality seed spreads various potato diseases from one area to the other. For instance, recent studies showed that bacterial wilt has spread nationwide and is embedded in the country's seed potato system due to the uncontrolled movement of latently infected seed $[10,14]$.

In 2015, the government of Ethiopia, in collaboration with development partners, developed a quality declared seed (QDS) production scheme with the objective of improving seed quality $[10,15]$. This scheme was established in response to the outbreak of bacterial wilt in the country and requires cooperatives to obtain certain certificates. Furthermore, there are seed standards that QDS cooperatives need to meet [15]. Among the standards, there is a zero-tolerance level for bacterial wilt. A considerable number of seed potato cooperatives in different parts of the country are now producing QDS. However, many seed potato cooperatives are still operating in the same way as they have been doing over the last 10 years. Therefore, both QDS and non-QDS seed potato cooperatives currently operate in the country's seed potato systems.

The Ethiopian seed potato market has been largely dominated by large organisational buyers like non-governmental organisations (NGOs), the Ministry of Agriculture, and the regional bureaus of agriculture $[11,13]$. Therefore, seed potato cooperatives did not have market problems until recently, and they were encouraged to intensify production and marketing. However, due to the rapid prevalence of bacterial wilt and the increasing awareness of the devastating nature of the disease among different actors in the country's potato production system, and in addition to the resulting zero-tolerance policy, seed potato cooperatives are now increasingly facing problems when selling seed potato tubers.

Potato farmers are interdependent, and individual efforts alone are not sufficient to combat bacterial wilt. Farmers share farm tools and exchange labour, and diseases can easily spread to neighbouring fields. Thus, ineffective practices by one farmer may result in a considerable impact on both, in the farm where these are carried out and in neighbouring farms [16]. As a result, the cooperatives mobilise their members to implement a range of recommended methods to manage bacterial wilt and other diseases on their potato fields, to produce disease-free seed and to prevent the disease from spreading. They also make efforts to monitor disease occurrence and its management [17].

Considering their interdependency, several studies on the management of bacterial wilt have shown the importance of collective action among smallholder potato farmers [16,18-20]. Furthermore, studies show that monitoring disease occurrence and management by seed potato cooperatives can play an important role in ensuring quality seed production $[9,13,17]$. The research to date has generally pointed out the importance of monitoring for collective action but does not elaborate in detail what a monitoring system entails and what the associated challenges are [12,17]. This study conducts a multidimensional investigation of the various practices involved in the monitoring of bacterial wilt management by seed potato cooperatives in Ethiopia and the challenges they encounter in doing so.

In the next sections, we first present the theoretical underpinning of the study and the associated research objective and research questions. We then proceed to describe the context of the two seed potato cooperatives selected for the study and the research methodology employed. This is followed by the presentation of our findings and an analysis and discussion of the implications for intervention and future research. 


\section{Theoretical Underpinning of the Study}

In this section, the concept of collective action and the essential elements of a monitoring system are described based on the common-pool resource literature.

Collective action is widely recognised in the literature as critical in case many individuals need to contribute to achieving a common objective. It is generally understood as the same individual action taken by a group of people with a common concern. Collective action has a wide range of applications, including the management of common-pool resources such as forests, irrigation water, fishing grounds, and grazing lands [21-23]. In recent years, the concept of collective action has also been applied in the context of complex agricultural issues such as invasive weeds $[24,25]$ and the marketing of agricultural produce [26-28]. For the latter, farmer groups and cooperatives have been promoted as ways to consolidate economies of scale, particularly for smallholder farmers [26,28].

Similarly to common-pool resources, the management of bacterial wilt has public good features. But the disease can be considered as a "public bad", a nondepletable negative phenomenon that does not get reduced when people are exposed to it [29]. For the effective management of this disease, collective action is essential. Isolated efforts of individual farmers cannot be effective since the disease spreads from field to field in a variety of ways, such as contaminated irrigation water, surface run-off, farm tools, and infected seed [30,31]. Notably, in the case of seed potato cooperatives, farmers need to cooperate and implement various disease management methods to produce and market quality seed potato. All farmers in a similar area would benefit from disease-free seed potato production.

Issues requiring collective action are often characterised by a tension between short-term individual interests and long-term collective interests, and individuals tend to free-ride [21,22,32,33]. For an effective and sustainable governance of common-pool resources through collective action, Ostrom [22] proposed eight design principles. A monitoring system is one of them. An effective monitoring system is expected to help address the problem of free-riders and audit the conditions of the common-pool resource [22].

The literature on common-pool resources shows that a monitoring system can be organised in two main ways: through self-monitoring and third-party monitoring. In the case of self-monitoring, the resource users are responsible for monitoring the condition of the resources and the behaviour of the community members, while in the case of third-party monitoring an external body is entirely in charge of the monitoring activities. The scholarly debate regarding these models is about the associated effectiveness and costs. Many scholars suggest that communities should have the capacity for self-monitoring and enforcement of sanctions to manage common-pool resources through collective action [34-37]. Agrawal and Goyal [38] also suggest self-monitoring as a more practical approach for a small group of common-pool resource users, given the high cost of third-party monitoring. Several studies show that a self-monitoring system organised by resource users is less expensive than a centralised external system [34,39-41]. However, self-monitoring tends to be more prone to free-riding than third-party monitoring [34]. This may explain the greater effectiveness of third-party monitoring found by Baland and Platteau [39] based on an analysis of many surveys on common-pool resources.

While there currently exists no comprehensive framework describing what precisely constitutes "a monitoring system", the literature indicates several elements of an effective monitoring system, including data collection, institutional arrangements (rules and standards), sanctions, decision-making, and the enforcement of sanctions [22,34,42]. Synthesising the scattered information available in the literature, we have identified and aggregated seven essential elements of a self-monitoring system for farmer cooperatives. These are (1) organisation of the monitoring system, (2) rules, standards, and sanctions, (3) data collection for monitoring, (4) decision-making, (5) enforcement of rule compliance with sanctions, (6) efficient communication, and (7) resources for monitoring (see Figure 1). 


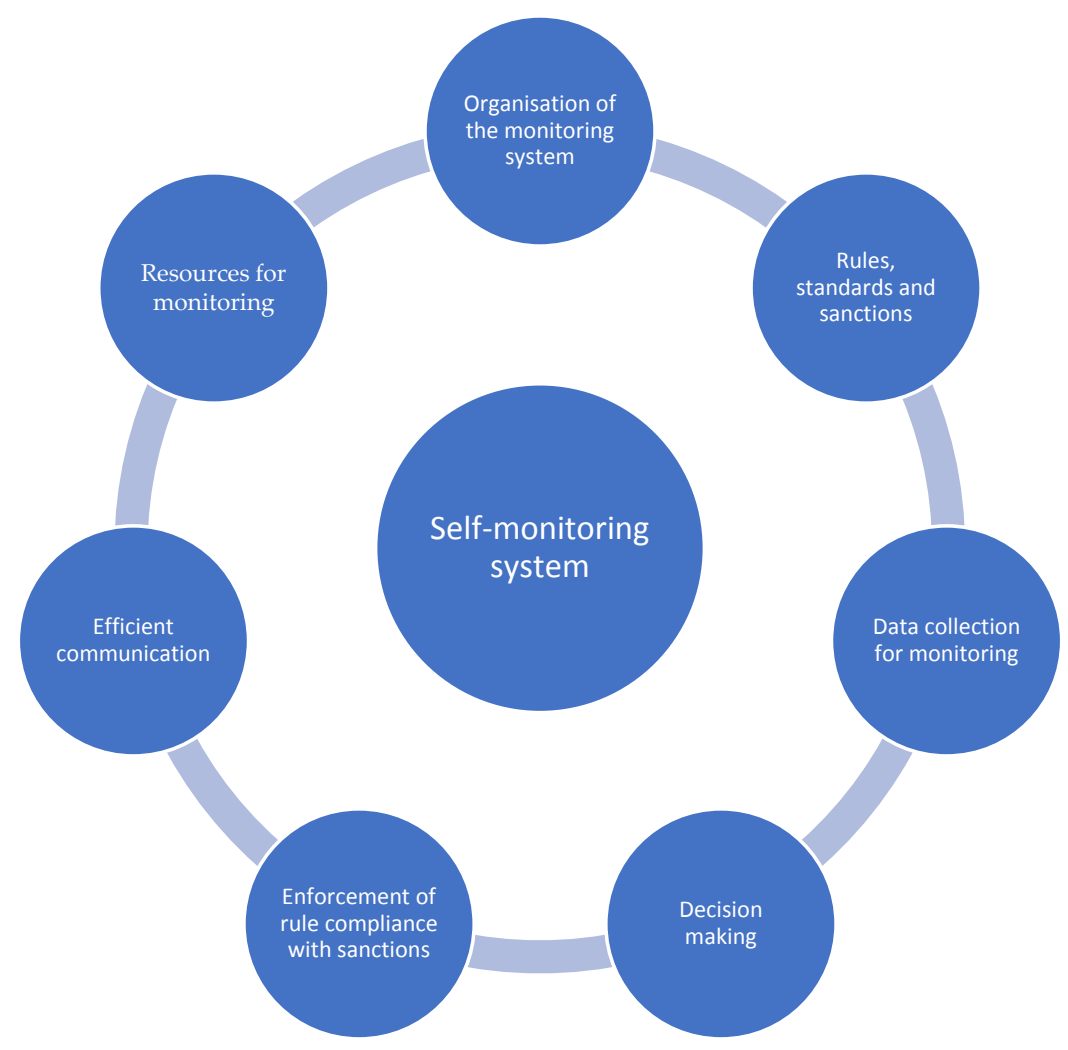

Figure 1. Elements of a self-monitoring system.

The organisation of an effective monitoring system for community-based natural resources management needs to be simple and cost-effective. Furthermore, it should be transparent in order to be trusted by the community members [43]. To this end, a locally-elected committee of users is usually responsible for the monitoring activities $[43,44]$.

Rules and standards are needed for optimal use of the available natural resources and to shape the behaviour of the resource users [34]. The community usually sets rules and standards for monitoring by consensus with the goal of sustainable use and management of natural resources $[34,38]$. In self-monitoring systems rules should be set regarding how to use and manage the existing natural resources without compromising their ecological sustainability. Sanctions are used to provide incentives for obedience to the rules and standards.

Data collection is a relevant monitoring activity usually involving periodic and repeated observations of different parameters [34]. For instance, for irrigation water, it is crucial to collect data on a regular basis on how much water the irrigators take at different times to ensure fair utilisation. Likewise, in the case of forest resources, data need to be collected on the status of the forest resources and the behaviour of the resource users [22]. Hence, the data collection of a monitoring system for disease management should include both the occurrence and locations of the public bad and actual disease management practices.

Decision-making is an important component of a monitoring system. Based on the monitoring information gathered, conclusions are drawn regarding the status of the public good or bad, and decisions are made regarding follow-up actions [22,38]. If the agreed rules on management practices are broken by resource users, it could be decided to enforce the agreed sanctions against free-riders.

Several studies show that rule compliance is affected by many factors, including the severity of sanctions, the behaviour of other resource users, social norms, personal morals, economic reasons, and local contexts $[22,38,45,46]$. Hence, in addition to the monitoring of the compliance to the rules, enforcing the compliance by implementing the collectively agreed sanctions is a vital element of an effective self-monitoring system. 
Communication is also essential in an effective self-monitoring system. The availability of ample opportunities for communication has been shown to enhance the levels of cooperation [47-49]. In a community-based approach to managing common-pool resources, communication enables, among others, collecting and sharing data, exchanging mutual commitments, reaching agreements on standards, sharing information for decision-making, enforcing rules, and developing trust in the monitoring system [47,49]. While face-to-face communication is known to be of particular importance $[49,50]$ in collective action settings, the increased connectivity through mobile phones and internet (Information and Communication Technologies, or ICTs) in Ethiopia may offer new opportunities for strengthening communication in such contexts [19,51].

ICTs can support the regular monitoring for the management of complex socio-ecological problems through collective action $[29,51]$. Among the emerging communication tools, mobile telephony has high penetration rates and a broad appeal to rural populations across developing countries. This has created new forms of communication and supported efforts to deal with various agricultural problems by enabling the farmers' access to knowledge and information [52-54]. Recent studies show that there have been successful initiatives involving the use of mobile phones for communication and information exchange to deal with complex agricultural problems. They have been used for the management of crop diseases, soil fertility management, and market issues in smallholder farmers' conditions $[53,55]$. Effective communication would thus make use of media that are available to the members of the community.

Finally, sufficient resources are essential for a long-lasting monitoring system. Particularly, the availability of sufficient financial resources is critical for a rural community without external financial support [43]. In addition to finance, pathogen detection kits are crucial for rapid disease diagnosis and the effective monitoring of potato disease occurrence in the field.

\section{Research Objective and Questions}

The main objective of the study is to assess the features of the existing monitoring systems for the collective management of potato bacterial wilt by seed potato cooperatives in the central highlands of Ethiopia. It investigates (a) the operationalisation of elements of the existing monitoring systems, and (b) the challenges associated with monitoring. The two underlying research questions are formulated as follows:

1. How do seed potato cooperatives operationalise the essential elements of a monitoring system for bacterial wilt management?

2. What are the challenges associated with existing monitoring systems and what implications do these challenges have for future interventions?

\section{Research Methodology}

\subsection{Description of the Seed Potato Cooperatives Selected for the Study}

For this study two seed potato cooperatives were selected from Wolmera and Doyogena districts. These are among the major potato-growing districts in the central highlands of Ethiopia. Wolmera district is located in the Oromia regional state, whereas Doyogena district is located in the Southern Nations, Nationalities, and People's Regional (SNNPR) state. In both districts, the rainfall pattern is bimodal, with a main rainy season (Meher) from June to September and a short rainy season (Belg) from February to May.

Since the new national policy addressing the outbreak of bacterial wilt occurrence came into existence, two kinds of potato seed cooperatives exist in Ethiopia: regular potato seed cooperatives and seed cooperatives working under the Quality Declared Seed system (QDS). The two key differences are: (1) cooperatives that produce regular seed potato operate using a legal certificate that they have received from a cooperative promotion office, whereas cooperatives that produce quality-declared seed potato need to get an additional competency certificate from the regulatory department of the 
regional bureau of agriculture and natural resources, and (2) for quality-declared seed producers there is a standard of zero-tolerance level for bacterial wilt, whereas for regular seed potato cooperatives there is no clear standard in this regard.

Taking the differences into account, two different cooperatives were selected for this study: Agota, a regular seed potato cooperative in Wolmera, and Wanjala, a QDS potato cooperative in Doyogena (see Figure 2 for their respective locations). The selection was made based on discussions with agricultural experts at the respective district offices of agriculture. Agota had 30 members at the time of the study, producing seed potatoes during both the Meher and Belg seasons. The farming system in Wolmera district is cereal-based, and potato is an important cash and food crop in the area. Wanjala has 18 members who collectively produce and market seed potato. The members of this cooperative produce potato during the Meher and Belg seasons, with major production during the Belg season. The farming system in Doyogena district is enset-based. Potato is the second most important crop after enset (Ensete ventricosum).

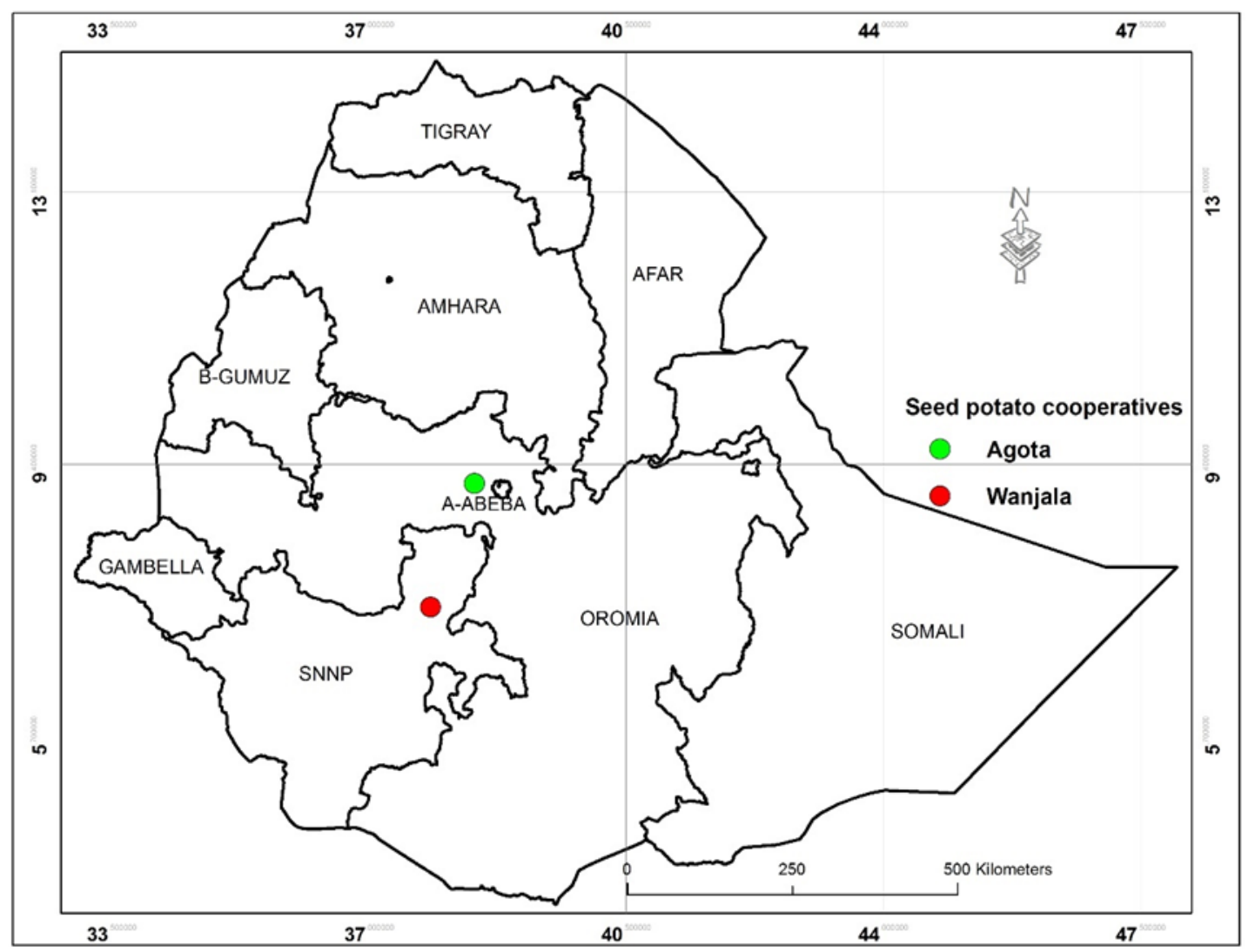

Figure 2. Location map of the studied seed potato cooperatives in Ethiopia.

\subsection{Data Collection and Analysis}

In order to gather relevant data for investigating the monitoring systems of the selected seed potato cooperatives, a multimethod approach was employed [56]. Data were collected through semi-structured interviews, reflective workshops, participant observation, and documents analysis.

Two rounds of interviews were conducted; one with six monitoring committee members (three farmers from each cooperative) and another with 18 seed potato farmers (10 farmers from Agota seed potato cooperative and eight farmers from Wanjala seed potato cooperative). Questions addressed to the monitoring committee members were related to the essential elements of the self-monitoring system of a collective bad, to the effectiveness of the system, and to challenges and suggestions for improving the system. Questions addressed to seed potato farmers focused on issues such as farmers' perception 
of the performance of the monitoring committee, communications and interactions, the efficacy of the monitoring system, and their trust in the decisions of the monitoring committee members.

Reflective workshops were organised to discuss the findings of the monitoring and associated challenges at the end of the production season. A total of respectively 30 and 18 seed potato farmers from Agota and Wanjala seed potato cooperatives participated in the reflective workshops conducted at the study sites. During the reflective workshops, the participants (seed potato farmers and monitoring committee members) discussed the reflection questions designed to facilitate the workshops. The reflection questions were designed to move from general questions about the importance of monitoring to control bacterial wilt to their perceptions about the key issues of monitoring disease occurrence, management, and associated challenges at their sites.

Participant observation was applied by partaking in seed potato cooperative meetings to capture the concerns and opinions of all the cooperative members. Besides, the potato fields were observed when the crop was at different growth stages, and diffused light stores owned by the seed potato cooperatives were visited. Finally, all relevant documents of the monitoring system were analysed, including cooperatives' minutes of meetings, internal bylaws, manuals and guidelines, and standards for seed potato production.

\section{Results}

In this section, the results of this study are presented as they relate to the essential monitoring system elements and associated challenges experienced by seed potato cooperatives: (1) organisation of a monitoring system, (2) rules, standards, and sanctions, (3) data collection for monitoring, (4) decision-making, (5) enforcement of sanctions, (6) communication, and (7) resources for monitoring.

\subsection{Organisation of the Monitoring Systems}

The study shows that both seed potato cooperatives recognised the importance of monitoring and organised a self-monitoring system. The cooperatives made efforts to perform monitoring activities to ensure the production of quality seed potato. The seed potato cooperatives have seed quality monitoring committees consisting of three members which are in charge of dealing with seed potato quality related issues. The committee members are elected by cooperative members to serve for a three-year term, and operate on a volunteer basis. They could be re-elected to serve for a second term of another three years based on their performance and the assessment of the cooperative members.

Both regular seed and QDS potato cooperatives had clearly defined roles and responsibilities for the monitoring committee members. From the interviews with the monitoring committee members and during reflective workshops, it was noted that the committee was supposed to visit each farmer's field to conduct the monitoring work. The committee mentioned that making regular field visits was essential to enhance the efficacy of the monitoring activity. But time did not allow them to do so, and the frequency of the field visits was limited to only about two to three times during different growth stages of the crop. During the field inspection, the committee members checked for the occurrence of visible potato diseases, and whether the farmers put the recommended management methods into practice or not. To ensure transparency, the committee members visited farmers' potato fields in the presence of the owner of the field.

In the QDS potato cooperative, agricultural extension officers and researchers provided some technical support to the seed quality monitoring committee. The researchers and extension officers joined the seed quality monitoring committee during a field inspection. According to the committee members, this support is crucial because they feel that the presence of the researchers can help them make a better diagnosis of disease incidence in potato fields. However, so far, the extent to which the researchers and extension officers support the monitoring work is limited, in the committee members' view. This support depends on the presence of development projects that promote the QDS scheme. During the reflective workshop, the monitoring committee members repeatedly expressed that the support from researchers and extension workers was not sufficient. Besides, the committee members 
stated that without the help of these actors, it would be difficult for their seed cooperative to continue producing quality-declared seed potatoes. They also expressed the importance of more training to perform the monitoring activity. It could also be expensive and challenging for the cooperatives to sustain the support from these actors due to their limited financial capacity.

The monitoring committee reported that the technical support they got from agricultural research institutes and agricultural offices was inconsistent. Furthermore, the monitoring committee members mentioned that sometimes they had to wait too long for the support from researchers, as they had to come from far away. The committee suggested that researchers and extension officers need to prioritise the support for the QDS potato cooperatives. Giving them priority is vital because the monitoring work is time-sensitive, and the disease is difficult to diagnose visually once the crop is mature.

In addition, seed potato farmers, the members of the seed potato cooperatives, have recently become vigilant about the practices of ware potato producers in their respective areas, in general, and of those with adjacent potato plots, in particular. Consequently, due to the contagious nature of the disease, seed potato cooperatives are compelled to recognise the importance of monitoring the practices of neighbouring ware potato farmers and disease incidences in their potato fields. However, the seed cooperatives do not have organisational and institutional arrangements that enable them to monitor the practices of ware potato farmers.

\subsection{Rules, Standards, and Sanctions}

Both QDS and regular seed potato producer cooperatives have an institutional arrangement (internal bylaws) to ensure quality seed production and enforcement of sanctions on non-adherents. The rules (bylaws) of the cooperatives encompass the details of how the cooperatives should operate as a business enterprise, requirements for membership, the role of the member farmers, and seed quality monitoring committee members, among others. The bylaws are written documents approved by the general assembly (members) of the cooperatives during their establishment. If there is a need to amend the bylaws, it happens during the annual general meeting of the cooperatives.

As specified in their bylaws, the cooperatives aggregate seed produced by their members, store them in common or individual diffused light stores (DLS), search for market opportunities, and sell collectively. In order to guarantee seed potato quality, the seed cooperatives also have rules and bylaws with regard to the management of pests and diseases. To a considerable degree, these rules and standards are linked to externally imposed standards for different types of cooperatives.

The regular seed potato cooperative (Agota) does not have a precise standard regarding the level of disease occurrence. It just mentioned that seed potato fields should be free from infection of bacterial wilt and other diseases. The committee members explained that-in connection with this-it orders the seed potato farmers to implement different methods to control bacterial wilt and maintain the hygiene of their potato fields. These methods include the roguing of potato plants with symptoms of bacterial wilt infection, crop rotation, use of healthy seed, runoff diversion, farm tools decontamination, and other sanitation measures.

QDS potato cooperatives have to meet much more rigorous standards than regular seed potato cooperatives (see Table 1). Among the standards, there is a zero-tolerance level for bacterial wilt, which is hard to meet given the prevalence of the disease in all major potato growing areas. Instead of enforcing zero-tolerance, the committee of the Wanjala cooperative usually advises farmers to uproot diseased plants and dispose of them safely to avoid further spreading of the disease. Another standard is that if disease infestation is observed on a potato field, potatoes should be banned from that field for five consecutive seasons. However, some QDS farmers mentioned that they were unaware of such requirements, while others stated that it is impossible to follow this standard given the shortage of land and wide prevalence of the disease. 
Table 1. Standards for quality-declared seed potato production (Source: Ethiopian Standards Agency (ESA), [15]).

\begin{tabular}{|c|c|c|c|c|c|c|}
\hline \multicolumn{3}{|r|}{ Parameters } & \multirow{2}{*}{$\begin{array}{c}\text { QDS } 1 \\
\text { Pre-basic or } \\
\text { Basic or C1 }\end{array}$} & \multirow{2}{*}{$\begin{array}{l}\text { QDS } 2 \\
\text { C2 or } \\
\text { QDS } 1\end{array}$} & \multirow{2}{*}{$\begin{array}{l}\text { QDS } 3 \\
\text { C3 or } \\
\text { QDS } 2\end{array}$} & \multirow{2}{*}{$\begin{array}{c}\text { QDS } 4 \\
\text {-QDS } 8 \\
\text { C4 or } \\
\text { QDS 3-7 }\end{array}$} \\
\hline 1 & & Class of seed as a source * & & & & \\
\hline 2 & Rota & ion (Minimum number of seasons) & 3 & 3 & 3 & 3 \\
\hline 3 & & tion Distance (Minimum meters) & 5 & 5 & 5 & 5 \\
\hline 4 & Off-ty & es and other cultivars (Maximum \%) & 2 & 3 & 4 & 5 \\
\hline \multirow{3}{*}{5} & \multirow{3}{*}{ Diseases } & Bacterial wilt (Maximum \%) & 0 & 0 & 0 & 0 \\
\hline & & $\begin{array}{c}\text { Potato leaf roll virus (PLRV), Potato } \\
\text { virus Y (PVY) and others (Maximum \%) }\end{array}$ & 5 & 10 & 12 & 13 \\
\hline & & Black leg (Maximum \%) & 0 & 0 & 0 & 0 \\
\hline
\end{tabular}

* Seed generations/categories: (C1) certified seed of the first generation, (C2) certified seed of the second generation, (C3) certified seed of the third generation, and (C4) certified seed of the fourth generation.

The monitoring committee members of the Wanjala cooperative highlighted the need for revising quality-declared seed standards such as the zero-tolerance level and the minimum isolation distance (see Table 1). They suggested that due to the expansion of the disease and the difficulty to find disease-free fields, there should be some level of tolerance for bacterial wilt incidence. The committee suggested the increase of the minimum isolation distance at least up to $10 \mathrm{~m}$ instead of the current $5 \mathrm{~m}$. They noted that varietal mix and disease transmission is possible with the currently practised $5 \mathrm{~m}$ of isolation distance.

Seed potato farmers and monitoring committee members in both cooperatives considered sanctions as an effective approach to ensure compliance with the bylaws and avoid free-riding. In response to bacterial wilt infestation and poor management practices, the main sanction that the committee members enforce is to reject selling the farmers' seed potatoes through their respective seed potato cooperatives. Farmers whose seed potato fields are infested are told to sell their produce as ware potato, and hence at lower prices. During the reflective workshops, the downside became clear: the farmers mentioned that the price of seed potato was two to three times higher than that of ware potato in both study sites. The other stiff sanction that the cooperatives are allowed to impose on members violating the rule is the cancellation of their cooperative membership. This sanction was also specified in the bylaws of the cooperatives.

\subsection{Data Collection for Monitoring}

During monitoring, committee members assessed disease occurrence only through visual observation of the potato fields. During field inspection, both committees collect data on different parameters, including potato variety, source of seed, size of potato field, disease occurrence, disease management practices, isolation distance between the seed potato field and other potato fields, crop rotation history, seed generation, and off-types, among others.

Most committee members mentioned that they often found it hard to properly diagnose disease incidence in the farmers' fields. The fact that the disease might not show symptoms (latent infection) further complicated the efficacy of the monitoring. They also referred to the difficulty of monitoring the implementation of disease management methods that are hard to trace, such as keeping farm hygiene and sanitation (decontamination of farming tools, washing shoes before getting into potato fields, removing and burning or burying infected plants, and use of disease-free seed). The committees have no appropriate mechanisms to figure out malpractices in these regards, apart from trusting the farmers' assertions. Finally, since the farmers know when the committee members will visit their fields, they always try to rogue all potato plants with symptoms of bacterial wilt infection, so that their potato fields look clean and healthy prior to the monitoring committees' visit. 
According to farmers and monitoring committee members, another challenge that constrained sufficient data collection for the monitoring activity was the inaccessibility of some potato fields. For example, in the Wanjala seed cooperative, as a solution to land shortage, QDS producers rent land outside their village to meet the land requirement for QDS production. At the same time, this practice posed new challenges. The farmers indicated that they could not frequently visit their potato fields or take actions they would have to take because of poor access to such remotely located fields. They also mentioned that it was difficult for them to protect their potato fields from human and livestock interferences. Likewise, monitoring committee members mentioned that such practice forced them to travel long distances to do their monitoring work.

Some QDS farmers in the Wanjala seed potato cooperative mentioned that the practice of ware producers affected their success in producing disease-free seed. They mentioned that since their land was bordered by ware potato fields, they faced challenges in meeting the minimum requirement of isolation distance of five meters between QDS potatoes and other potato fields.

In the case of the Agota seed potato cooperative, the monitoring committee described that some farmers living elsewhere came to their village to grow potatoes. These farmers accessed potato fields through rental arrangements for one or more seasons. It was difficult to monitor the practices of those farmers and to oblige them to control the disease, as they do not belong to that community. In such cases, the committee mentioned that they try to put pressure on the farmers who rent their lands to external farmers so that they in turn compel those farmers to control the disease by properly implementing different disease management methods. The committee revealed that such efforts were not effective enough to control the disease. Going forward, the committee thought it might be good to convince the farmers who rent their fields to other farmers to include disease management practices in the agreement they sign for land rental.

When asked during the reflection workshop about the possibility of doing the monitoring work on a weekly basis, the farmers and the monitoring committee members indicated that this was an unrealistic and unattainable proposal. They recognised the importance of improving the frequency of monitoring, considering the complexity of the disease problem. However, the monitoring committee enunciated that they did not have time to do so, as they were volunteers and had to do their own various farming activities.

\subsection{Decision-Making}

The monitoring committees make decisions based on field inspection findings and share their findings with cooperative members at regular meetings. They try to substantiate their findings with evidence and take minutes of the meetings. However, despite the visible prevalence of bacterial wilt in both study sites, the monitoring committees reported only few cases of rejection of potato fields as seed. This is also true for the QDS cooperative that officially has a zero-tolerance policy for bacterial wilt. They tend to give warnings and provide recommendations rather than to take the agreed sanctions. The committees also stated that after each season they organise meetings to discuss the challenges they faced during a particular growing season and how to avoid them in the next season.

The monitoring committee members of the QDS cooperative stated that agricultural extension officers supported them in explaining their reasons for the rejection of seed potatoes. Most farmers also mentioned the facilitation role of the extension officers as important. Some seed farmers mentioned that they trust the extension officers more than the monitoring committee members. In addition, some farmers felt that the decisions made by the committee were biased and unacceptable. These farmers were mostly those who got their seed potato field rejected at least once. These farmers made comments such as:

"The decision of the monitoring committee is partial because all the committee members' potato fields get accepted every time. But they reject those of other farmers. How can their fields be accepted every time?" 
"The monitoring committee members sometimes undermine when they observe considerable problems on potato fields of their relatives and make a positive decision."

The monitoring committee rejects mainly the fields of the farmers who failed or refused to implement the recommendations given by the committee in a previous season. For example, during the reflective workshop, one of the farmers who was a member of the Agota seed cooperative complained about the decision made by the monitoring committee. He said that the committee rejected his field although he implemented the recommendations given by the committee. The committee mentioned that the field of this particular farmer was infested by bacterial wilt and he could not rogue all plants with symptoms of bacterial wilt infection, since they were too many.

The other constraint that the farmers mentioned about the decisions of the monitoring committee was a lack of transparency. The monitoring committee members approving potato fields that should not be accepted for seed appeared to create the farmers' distrust in the monitoring process. For instance, while stating their distrust in the monitoring committee, farmers from the Agota seed potato cooperative said the following:

"My potato field was cleaner than that of my neighbour, but the committee rejected my field and accepted that of my neighbour. I did not know on what basis they made their decision."

“The amount of seed that some farmers bring to the cooperatives' diffused light store (DLS) is sometimes far more than what they can actually harvest from their small plot of land. These farmers might bring their neighbours' or relatives' ware potato produce to sell through the cooperative as seed."

\subsection{Enforcement of Rule Compliance with Sanctions}

As mentioned earlier, the monitoring committee members in both types of seed potato cooperatives-QDS and regular-rarely enforced sanctions by rejecting potato fields infected by bacterial wilt. In most instances, the committee members compromised and showed sympathy. Indeed, when the disease infestation was low, the committee typically advised the farmers to properly remove (rogue) and dispose of the plants with symptoms of bacterial wilt infection, instead of rejecting the infested field. In most cases, they opted to limit their punishment to verbal warnings in spite of the visible occurrence of bacterial wilt in the potato fields. Likewise, the two cooperatives had never imposed the sanction of banning farmers from the cooperative. Some committee members mentioned that a cancellation of seed producers' cooperative membership is not easy to impose. But other committee members and some farmers emphasised the importance of imposing this sanction on farmers who repeatedly violate cooperative rules.

The monitoring committee members from both cooperatives reported that they frequently face challenges in enforcing the sanctions. Farmers whose fields were rejected did not easily accept the decision of the committee. For instance, one of the committee members from the Wanjala seed potato cooperative said:

"Some farmers get furious when we do not allow their potatoes to be sold as quality-declared seed due to bacterial wilt problems."

According to monitoring committee members, the generality and lack of precision in the standards for regular seed potato cooperatives tended to reinforce the emergence of complaints and tense debates whenever potato fields were rejected on the basis of disease infestation. Affected farmers tended to deny the occurrence of the disease in their fields, and some farmers struggled to manipulate their potato fields by removing infected plants to make them attractive to the committee members.

\subsection{Efficient Communication}

Monitoring committee members communicate with each farmer through various mechanisms. They regularly organise meetings to discuss and communicate face-to-face with each cooperative 
member about their plans, the progress of different activities, agricultural inputs availability, market issues, disease problems, and other matters. The cooperatives write letters to their cooperative members, particularly when they communicate critical issues such as the rejection of their potato fields on the basis of severe disease infestation.

The comments given by the farmers and committee members stressed the prominent place that mobile phones had in communication for monitoring collective action by seed potato cooperatives. During the interviews, one of the committee members from the Agota seed cooperative said the following:

"Before a few years, we used to visit each farmer's house and call the farmers for a meeting, as most farmers did not have mobile phones. But now almost all farmers use mobile phones and we easily communicate with each other."

Similarly, when asked how mobile phones supported the monitoring of collective action, a farmer from the Wanjala seed potato cooperative said:

"Monitoring committee members call and ask us when they plan to do potato field inspection.

We discuss through the mobile phone and make an appointment on a convenient date."

Although mobile phone communication appeared to have had a prominent place in supporting the logistics of the seed potato cooperatives, farmers mentioned lack of access to electricity to charge their mobile phones and network interruptions as challenges. These problems constrained the effective and regular use of mobile phones for communication. More generally, farmers reported that regular communication with the monitoring committee members helps them understand the status of disease occurrence in their community, while the committee members emphasised the importance of timely communication with farmers to give feedback and encourage them to take necessary measures to improve the quality of seed. One of the challenges that the committee mentioned in relation to communication was that some farmers did not regularly attend meetings due to various social problems.

\subsection{Resources for Monitoring}

The monitoring committee serves on a volunteer basis, and seed potato cooperatives do not incur a considerable cost for the service that the committee provides, apart from a limited daily allowance which is intended to cover operational costs. Since effective monitoring entails visiting several scattered potato fields on a regular basis, monitoring committee members suggested the importance of increasing the incentives to encourage them to do the monitoring activity diligently on a regular basis. During the reflective workshop, the committee also repeatedly raised the importance of increasing the incentives allocated by the cooperatives to the monitoring activity. Seed potato farmers also reported that regular monitoring of many farmers' fields was a labour-intensive activity and that the monitoring committee members deserved additional (financial) incentives. Some farmers, however, were hesitant about the increment of allowance for the committee, stating that they did not have enough money to pay raised fees. Particularly, a considerable number of farmers from the Agota seed cooperative explained that due to the lack of a reliable market for their seed produce in recent years, they started selling seed potatoes to ware potato traders during harvesting time. As a result, these farmers were not in favour of increasing the allowance for the monitoring committee.

When asked about the possibility of using a third-party monitoring for the collective management of bacterial wilt, both farmers and monitoring committee members reported that there was no third-party that could be involved in such activities in the country. They also highlighted their concern, as this would be beyond the financial capacity of their cooperatives and individual farmers. The committee members reported that they participated in some capacity development trainings organised by the government and non-governmental organisations, but felt that the capacity development support was insufficient, and stated that they do not have access to kits to help them make proper disease diagnoses. 


\section{Analysis and Discussion}

Seed potato cooperatives have indeed established a working monitoring system to stimulate disease management and improve the quality of the seed production by their members. Moreover, the framework regarding the essential elements of an effective monitoring system that we compiled on the basis of literature on the collective management of common-pool resources proved useful for describing the way in which cooperatives have operationalised their monitoring system. The presence of an organised self-monitoring system among the cooperatives can-in principle-contribute to the supply of quality seed and the control of bacterial wilt [57-59]. However, the findings of this study indicate that monitoring disease occurrence and management is a complex and multifaceted activity that faces many challenges.

\subsection{Challenges for Effective Monitoring}

Despite the existence of an organised monitoring system to ensure quality seed potato production by seed potato cooperatives, it is clear that the functioning of the system faces many challenges in light of the wide spread of bacterial wilt in the country's major potato production areas. An overview of the experienced challenges is provided in Table 2.

Proper disease diagnosis skills are vital for the effective monitoring of the occurrence of the disease and farmers' management practices. However, the study showed that the monitoring committee members depended on visual observation to collect data on the incidence of bacterial wilt in seed potato fields. As the disease may not always show the symptoms due to latent infection [60-62], the committee may fail to detect the disease. As a result, seed cooperatives could produce and market infected seed, which could aggravate the spread of the disease. Such circumstances could damage the reputation of all seed producers belonging to that cooperative. To reduce such risks, the committee would need to have access to kits that support a proper and regular disease diagnosis at the field level. However, the financial and human resources available to cooperatives do not allow for this.

Several studies on common-pool resource management show that sanctions enhance compliance with the rules and help avoid the free-riders problem [34,63]. In the case of seed potato cooperatives, we have observed that the bylaws do include stiff sanctions (i.e., withholding of access to the seed potato market) that the monitoring committees are supposed to enforce on the basis of observed disease infestation. In practice, however, the monitoring committees seemed to compromise in enforcing sanctions, as only a few cases of rejection were reported by the cooperatives. In addition to the lenient enforcement practice, compliance with the rules may have been poor due to several other factors, such as personal morals, social norms, legitimacy, and contextual factors [64,65].

In relation to decision-making, our findings indicate that the trust between members of seed potato cooperatives and monitoring committees was limited. The decisions of monitoring committees were frequently contested, and both parties raised questions about each other's integrity. This has important implications, since trust among key stakeholders is imperative for the effective management of common-pool resources [34,40]. To develop trust, the monitoring committee members need to make their decision-making process more transparent, be consistent in their decisions, and also apply the rules to their own seed potato fields.

A complicating factor in this regard is that the monitoring system only applies to seed potato producers, while neighbouring producers of ware potatoes are also a source of disease infestation. This makes it difficult to hold members fully responsible for disease occurrence and is likely to contribute to the dilemma that monitoring committees face in enforcing bylaws and to the contestation of the decisions made. Thus, the current monitoring system of the seed cooperatives needs to go beyond the members and to find alternatives to involve ware potato producers in the monitoring. Due to the collective risk that the disease poses, seed and ware potato farmers need to make concerted efforts to deal with the disease. 
Table 2. Challenges reported and observed in the monitoring system.

\begin{tabular}{|c|c|}
\hline Element of the Monitoring System & Challenges Observed \\
\hline Organisation of the monitoring system & $\begin{array}{l}\text { - } \quad \text { Volunteer basis constrains regular monitoring } \\
\text { Members of committee are not fully independent, since they } \\
\text { need to monitor their own fields as well } \\
\text { - Boundary of the organisation does not coincide with } \\
\text { boundaries relevant to the disease (in terms of members } \\
\text { and distance) } \\
\text { - Organisation has weak linkages with research and extension }\end{array}$ \\
\hline Rules, standards, and sanctions & $\begin{array}{l}\text { - For regular cooperatives the rules are formulated in general } \\
\text { terms and therefore ambiguous } \\
\text { Rules only apply to fields of seed potato producers and not to } \\
\text { ware producers }\end{array}$ \\
\hline Data collection for monitoring & $\begin{array}{l}\text { - Visual observation is a sub-optimal technology for } \\
\text { data collection } \\
\text { - } \quad \text { Proper diagnostic tools are lacking } \\
\text { - Frequency of data collection is generally insufficient, and even } \\
\text { more so in rented fields outside the community }\end{array}$ \\
\hline Decision-making & $\begin{array}{l}\text { - } \quad \text { Decisions related to enforcement are frequently contested } \\
\text { - Transparency of decision-making process is regarded as } \\
\text { sub-optimal, creating distrust }\end{array}$ \\
\hline $\begin{array}{l}\text { Enforcement of rule compliance } \\
\text { with sanctions }\end{array}$ & $\begin{array}{l}\text { - Fields are only occasionally rejected, even in cases where the } \\
\text { rules would justify this } \\
\text { - } \quad \text { Frequent offenders are never banned from the cooperative }\end{array}$ \\
\hline Efficient communication & $\begin{array}{l}\text { - Boundary of communication networks does not coincide with } \\
\text { boundaries relevant to the disease } \\
\text { - Pre-announcement of field inspections by mobile phone } \\
\text { enables farmers to hide disease infestation } \\
\text { - } \quad \text { Participation in face-to-face assembly meetings is insufficient }\end{array}$ \\
\hline Resources for monitoring & 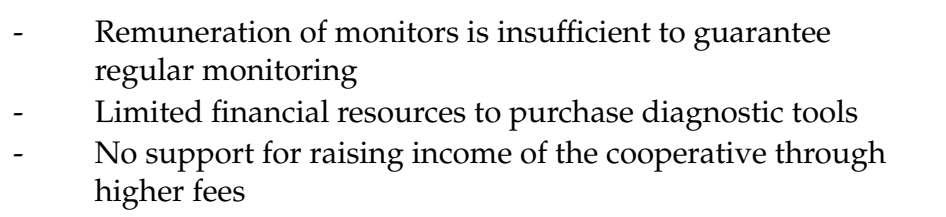 \\
\hline
\end{tabular}

Arguably, the communication element of the monitoring system poses relatively fewer challenges, not least since both farmers and monitoring committee members have benefitted from new opportunities created by the widespread availability of mobile phones. Committee members can easily communicate with each other and with seed potato growers, extension officers, and researchers. Farmers also stated that the expansion in mobile telephony facilitates easy communication with each other and with their respective cooperatives. This is in line with the report of the Ethiopian Agricultural Transformation Agency on how mobile telephony has created an opportunity to deliver agricultural information to many smallholder farmers in the country and how mobile phone communication has become a 
common practice among many smallholder farmers in Ethiopia $[55,66,67]$. The downside of the use of mobile phones in planning field inspections is that farmers knew when inspectors were coming and had time to conceal disease infestation. In addition, challenges were reported in relation to the participation of members in face-to-face group meetings that were relevant to the functioning of the cooperative. Moreover, it is questionable whether the current boundaries of cooperatives and their communication networks are appropriate in view of the mechanisms involved in the spreading of the disease. One may argue that more intensive communication is needed across broader geographical spaces, as well as with different types of farmers (seed potato producers and ware potato producers alike) in the same community.

From a historical perspective, the observed challenges relate to the ways in which seed potato cooperatives were established. During their establishment, the development organisations that facilitated their establishment did not consider the social and ecological interdependencies between ware potato producers and seed producers. They facilitated the establishment of many seed potato cooperatives as an innovative initiative in response to the limited seed potato supply in the country [11]. The ecological and social context of the farmers in view of the occurrence and management of potato diseases like bacterial wilt were not well considered during this period. Consequently, even though the seed potato cooperatives have been able to enhance the seed potato supply in the country $[7,12]$, nowadays almost all of them are experiencing serious problems due to their limited capacity to effectively respond to the emerging and devastating potato disease caused by bacterial wilt $[10,68]$.

All in all, the results of this study confirmed that both regular seed and QDS potato cooperatives were not in a position to effectively monitor collective efforts to multiply seed potato by controlling bacterial wilt with a zero-tolerance level. The prevalence of bacterial wilt has complicated the management of the disease and the practice of quality seed production. Some seed producers reported selling their seed produce as ware potato due to the lack of market likely due to the problem of bacterial wilt. This has a huge implication for the already underdeveloped seed system in the country. If seed producers turn back to growing ware potato, the gap between the demand and supply of seed will be widened, resulting in the limited availability of seed potatoes. Further potato diseases like bacterial wilt will spread more, as farmers will be forced to repeatedly use infected ware potato tubers as seed. This can indeed jeopardise the food and nutrition security initiatives in different parts of the country, since potato is a strategic crop that has been promoted to address food insecurity problems. Tensions between food insecurity pressures and the attention given to seed potato quality can also have a significant negative effect on the efforts towards the effective management of the disease. Therefore, over the coming years, the problem of bacterial wilt can be aggravated unless the farmers and other actors such as research, extension offices, and non-governmental organisations make concerted efforts to deal with it.

\subsection{Implications for Future Interventions}

Although the seed potato cooperatives had organised systems to monitor disease occurrence and its management for quality seed production, they were underprepared to respond to the recently emerged but widely spreading potato disease, bacterial wilt. This raises the question of how the monitoring system can be made more effective.

In the literature on collective action, both self-monitoring and third-party monitoring are recommended, even though there has been a debate among several scholars in relation to the effectiveness and costs associated with the two approaches. Some researchers advocate self-monitoring [37,38], while others suggest that third-party monitoring is more effective [34,39]. Even though our study points to important weaknesses in the self-monitoring system, there are also strong indications that third-party monitoring is currently not feasible for seed potato cooperatives, in view of various conditions such as the limited financial capacity of smallholder farmers and their cooperatives, and the absence of an organisation that can provide third-party monitoring services in the country. This is confirmed in many studies showing that the implementation of formal seed systems is not feasible in low-income 
countries due to technical and institutional constraints [13,69,70]. Likewise, in Ethiopia, the role of seed cooperatives has been and will continue to be significant in potato seed systems, since a formal seed certification system cannot be developed at a sufficient scale anytime soon $[13,70,71]$. This underscores the importance of strengthening the self-monitoring capacity of the existing seed potato cooperatives for the subsistence of seed potato producers.

While the current self-monitoring system is unable to address the disease, it is important to recognise that this inability relates to the enormous prevalence of the disease in the country and to the fact that no adequate treatment exists. Hence, the cooperatives are facing a near impossible task, also because their neighbouring ware potato producers are not currently enrolled in the cooperative efforts.

While it is relevant to eventually address all reported challenges through training, resource acquisition, and measures to enforce sanctions and enhance transparency and combat distrust, the most important issue to be dealt with in the short term is the creation of better linkages between seed potato farmers and ware potato farmers. This is because any effort from the side of seed potato cooperatives is bound to fail if it is not coordinated and negotiated with ware producers. In essence, ware producers need to become an integral part of the entire monitoring system. In addition, it is important to invest in technical and agronomic research aimed at finding strategies to get rid of bacterial wilt once the disease has established itself. Moreover, it is important to identify and protect areas in communities and in Ethiopia where bacterial wilt is not yet established.

This means that on top of monitoring potato fields for disease occurrence and farmer practices, it is important to monitor seed movement within the community. Both incoming and outgoing seed potato to and from the community needs to be monitored. This could bring about the need for strong peer monitoring, which has to be well integrated to support the efforts of the monitoring committee.

\subsection{Implications for Future Research on Monitoring Systems}

As part of this study, we developed a novel framework consisting of essential elements of monitoring systems for disease management. The current study suggests that the framework is useful for describing and analysing the way in which seed potato cooperatives in Ethiopia engage with disease monitoring, and that it can serve to diagnose and categorise challenges and reflect upon solutions. Since the elements in the framework are quite general, it is likely that it can be applied to describe and evaluate monitoring systems in other contexts, including monitoring systems for other crops and diseases. Comparative analysis across multiple cases and contexts can potentially yield interesting insights, for example in how specific characteristics of diseases (e.g., spreading mechanisms) can pose specific challenges and demands on the operationalisation and design of effective monitoring systems for disease management, or in how specific social, economic, and political conditions in society may enable or constrain the emergence and implementation of such systems. Thus, the framework may orient future research and open up interesting areas of investigation, which can at the same time contribute to a further refinement of the constituting elements of the framework for different situations.

\section{Conclusions}

Our study has demonstrated that seed potato cooperatives do indeed have a reasonably well elaborated self-monitoring system, geared towards safeguarding seed quality and disease management. This reflects one of the design principles for sustainable and effective management of common-pool resources, which in our case relates to the prevention of a public bad. However, it seems that seed potato cooperatives in Ethiopia are currently underprepared to control bacterial wilt. The monitoring systems that the seed potato cooperatives put in place do not match the dynamics of the disease and its wide prevalence. Governmental and non-governmental organisations operating in the country's potato innovation system can therefore benefit from the findings of this study for a better understanding of the complexity of the monitoring activity for quality seed production and the management of the disease. In order to effectively respond to the increasing disease pressure, the existing self-monitoring activity of seed potato cooperatives needs to be improved in several respects. This includes the enhancement 
of disease diagnosis, the strict enforcement of sanctions, greater transparency in decision-making, and the extension of the monitoring system towards seed movement. However, the most important measure to be taken in the short term is to ensure that producers of ware potatoes are included in the self-monitoring system. Any measure taken to combat the disease on the fields of seed potato producers is bound to fail if neighbouring ware producers are not involved in collective action. Finally, further research should be done to understand risk factors for the disease and to investigate alternative management methods that are feasible in a smallholder farmers' context for an effective collective action to deal with the disease.

Author Contributions: Conceptualization, S.T., R.L., and C.L.; methodology, S.T., R.L., and C.L.; validation, S.T., R.L., and C.L.; formal analysis, S.T., R.L., and C.L.; investigation, S.T.; data curation, S.T.; writing-original draft preparation, S.T.; writing-review and editing, R.L., C.L., B.v.M., P.C.S., and B.L. All authors have read and agreed to the published version of the manuscript.

Funding: This research was funded by the Interdisciplinary Research and Education Fund (INREF) of Wageningen University and Research and the International Potato Centre (CIP). Additional funding was provided by the CGIAR Research Program on Roots, Tubers, and Bananas (RTB) and supported by CGIAR Trust Fund Contributors (https://www.cgiar.org/funders/), along with the US Agency for International Development (USAID), Federal Award no. 663-G-00-09-00420.

Conflicts of Interest: The authors declare no conflict of interest.

\section{References}

1. Devaux, A.; Kromann, P.; Ortiz, O. Potatoes for sustainable global food security. Potato Res. 2014, 57, 185-199. [CrossRef]

2. Haverkort, A.J.; Struik, P.C. Yield levels of potato crops: Recent achievements and future prospects. Field Crops Res. 2015, 182, 76-85. [CrossRef]

3. Harahagazwe, D.; Condori, B.; Barreda, C.; Bararyenya, A.; Byarugaba, A.A.; Kude, D.A.; Lung'aho, C.; Martinho, C.; Mbiri, D.; Nasona, B.; et al. How big is the potato (Solanum tuberosum L.) yield gap in Sub-Saharan Africa and why? A participatory approach. Open Agric. 2018, 3, 180-189. [CrossRef]

4. Agricultural Sample Survey Report on Area, Production and Farm Management Practice of Belg Season Crops Private Peasant Holdings; Statistical Bulletin; CSA. (Central Statistical Agency): Addis Ababa, Ethiopia, 2016; Volume V.

5. FAO. Potato World: Africa-International Year of the Potato 2008: New light on a hidden treasure; Food and Agriculture Organization of the United Nations: Rome, Italy, 2008.

6. Haverkort, A.J.; van Koesveld, M.J.; Schepers, H.T.A.M.; Wijnands, J.H.M.; Wustman, R.; Zhang, X. Potato prospects for Ethiopia: On the road to value addition. P.P.O. Publication 528. Lelystad Ppo Agv 2012, 1, 1-66.

7. Woldegiorgis, G.; Negash, K.; Solomon, A.; Chindi, A.; Lemaga, B. Participatory Potato Seed Production: Experiences from West and Southwest Shewa, and Gurage Zones. In Seed Potato Tuber Production and Dissemination: Experiences, Challenges and Prospects, Proceedings of the National Workshop on Seed Potato Tuber Production and Dissemination, Bahir Dar, Ethiopia, 12-14 March 2012; Woldegiorgis, G., Berihun, B., Schultz, S., Eds.; EIAR: Addis Ababa, Ethiopia, 2013.

8. Sharma, K.; Woldegiorgis, G.; Tessema, L.; Desta, T.; Zegeye, W.; Teklu, M.A.; Abdurahman, A.; Lunt, T.; Smith, J.; Schulte-Geldermann, E. Tackling Bacterial Wilt of Potato in Ethiopia. Key Messages; Policy Brief No.1; International Potato Center: Lima, Peru, 2018; pp. 1-4.

9. Ayana, A.; Borman, G.; Subedi, A.; Abay, F.; Mohammed, H.; Nefo, K.; Dechassa, N.; Dessalegn, T. Integrated seed sector development in Ethiopia: Local seed business development as an entrepreneurial model for community-based seed production in Ethiopia. In Proceedings of the Community Seed Production, Addis Ababa, Ethiopia, 9-11 December 2013; pp. 88-97.

10. 12th Six-Month Program Report. Better Potato for Better Life Project; International Potato Center: Lima, Peru, 2016.

11. Hirpa, A.; Meuwissen, M.P.M.; Tesfaye, A.; Lommen, W.J.M.; Lansink, A.O.; Tsegaye, A.; Struik, P.C. Analysis of seed potato systems in Ethiopia. Am. J. Potato Res. 2010, 87, 537-552. [CrossRef] 
12. Sisay, D.T.; Verhees, F.J.; van Trijp, H.C. Seed producer cooperatives in the Ethiopian seed sector and their role in seed supply improvement: A review. J. Crop Improv. 2017, 31, 323-355. [CrossRef]

13. Schulz, S.; Woldegiorgis, G.; Hailemariam, G.; Aliyi, A.; van de Haar, J.; Shiferaw, W. Sustainable seed potato production in Ethiopia: From farm-saved to quality declared seed. In Seed Potato Tuber Production and Dissemination: Experiences, Challenges and Prospects; Proceedings of the National Workshop on Seed Potato Tuber Production and Dissemination, Bahir Dar, Ethiopia, 12-14 March 2012; Woldegiorgis, G., Berihun, B., Schultz, S., Eds.; EIAR: Addis Ababa, Ethiopia, 2013.

14. Abdurahman, A.; Griffin, D.; Elphinstone, J.; Struik, P.C.; Schulz, S.; Schulte-Geldermann, E.; Sharma, K. Molecular characterization of Ralstonia solanacearum strains from Ethiopia and tracing potential source of bacterial wilt disease outbreak in seed potatoes. Plant Pathol. 2017, 66, 826-834. [CrossRef]

15. Quality Declared Seed (QDS)_Vegetatively Propagated Potato Seed_Specification, 1st ed.; ESA: Addis Ababa, Ethiopia, 2015.

16. Tafesse, S.; Damtew, E.; van Mierlo, B.; Lie, R.; Lemaga, B.; Sharma, K.; Leeuwis, C.; Struik, P.C. Farmers' knowledge and practices of potato disease management in Ethiopia. Njas Wagening. J. Life Sci. 2018, 86-87, 25-38. [CrossRef]

17. Tadesse, Y.; Almekinders, C.J.M.; Griffin, D.; Struik, P.C. Collective Production and Marketing of Quality Potato Seed: Experiences from Two Cooperatives in Chencha, Ethiopia. Forum Dev. Stud. 2020, 47, 139-156. [CrossRef]

18. Campilan, D. Linking social and technical components of innovation through social learning. In Wheelbarrows Full of Frogs: Social Learning in Rural Resource Management: International Research and Reflections; Leeuwis, C., Pyburn, R., Eds.; Koninklijke Van Gorcum: Assen, The Netherlands, 2002; pp. 135-146.

19. Damtew, E.; Tafesse, S.; Lie, R.; van Mierlo, B.; Lemaga, B.; Sharma, K.; Struik, P.C.; Leeuwis, C. Diagnosis of management of bacterial wilt and late blight in potato in Ethiopia: A systems thinking perspective. Njas-Wagening. J. Life Sci. 2018, 86-87, 12-24. [CrossRef]

20. Lemaga, B.; Kakuhenzire, R.; Kassa, B.; Ewell, P.; Priou, S. Integrated Control of Potato Bacterial Wilt in Eastern Africa: The Experience of African Highlands Initiative: Bacterial Wilt Disease and the Ralstonia Solanacearum Species Complex; Allen, C., Prior, P., Hayward, A.C., Eds.; American Phytopathological Society Press: St. Paul, MN, USA, 2005; pp. 145-157.

21. Meinzen-Dick, R.; DiGregorio, M.; McCarthy, N. Methods for studying collective action in rural development. Agric. Syst. 2004, 82, 197-214. [CrossRef]

22. Ostrom, E. Governing the Commons: The Evolution of Institutions for Collective Action; Cambridge University Press: NewYork, NY, USA, 1990.

23. Abdullaev, I.; Kazbekov, J.; Manthritilake, H.; Jumaboev, K. Water user groups in Central Asia: Emerging form of collective action in irrigation water management. Water Resour. Manag. 2010, 24, 1029-1043. [CrossRef]

24. Marshall, G.R.; Coleman, M.J.; Sindel, B.M.; Reeve, I.J.; Berney, P.J. Collective action in invasive species control, and prospects for community-based governance: The case of serrated tussock (Nassella trichotoma) in New South Wales, Australia. Land Use Policy 2016, 56, 100-111. [CrossRef]

25. Yung, L.; Chandler, J.; Haverhals, M. Effective weed management, collective action, and landownership change in western Montana. Invasive Plant Sci. Manag. 2015, 8, 193-202. [CrossRef]

26. Barham, J.; Chitemi, C. Collective action initiatives to improve marketing performance: Lessons from farmer groups in Tanzania. Food Policy 2009, 34, 53-59. [CrossRef]

27. Fischer, E.; Qaim, M. Linking smallholders to markets: Determinants and impacts of farmer collective action in Kenya. World Dev. 2012, 40, 1255-1268. [CrossRef]

28. Ochieng, J.; Knerr, B.; Owuor, G.; Ouma, E. Strengthening collective action to improve marketing performance: Evidence from farmer groups in Central Africa. J. Agric. Educ. Ext. 2018, 24, 169-189. [CrossRef]

29. Leeuwis, C.; Cieslik, K.; Aarts, M.; Dewulf, A.; Ludwig, F.; Werners, S.E.; Struik, P.C. Reflections on the potential of virtual citizen science platforms to address collective action challenges: Lessons and implications for future research. Njas-Wagening. J. Life Sci. 2018, 86-87, 146-157. [CrossRef]

30. Hayward, A.C. Biology and epidemiology of bacterial wilt caused by Pseudomonas solanacearum. Annu. Rev. Phytopathol. 1991, 29, 65-87. [CrossRef]

31. Janse, J.D. Potato brown rot in Western Europe-history, present occurrence and some remarks on possible origin, epidemiology and control strategies. Eppo Bull. 1996, 26, 679-695. [CrossRef] 
32. Leeuwis, C. Communication for Rural Innovation. Rethinking Agricultural Extension, 3rd ed.; Blackwell Science: Oxford, UK, 2004.

33. Ostrom, E. Building trust to solve commons dilemmas: Taking small steps to test an evolving theory of collective action. In Games, Groups, and the Global Good; Springer: Berlin, Germany, 2009; pp. 207-228.

34. Ostrom, E. Doing institutional analysis digging deeper than markets and hierarchies. In Handbook of New Institutional Economics; Springer: Dordrecht, The Netherlands, 2005; pp. 819-848.

35. Pretty, J. Social capital and the collective management of resources. Science 2003, 302, 1912-1914. [CrossRef]

36. Singleton, S. Co-operation or capture? The paradox of co-management and community participation in natural resource management and environmental policy-making. Environ. Politics 2000, 9, 1-21. [CrossRef]

37. Singleton, S.; Taylor, M. Common property, collective action and community. J. Theor. Politics 1992, 4, 309-324. [CrossRef]

38. Agrawal, A.; Goyal, S. Group size and collective action: Third-party monitoring in common-pool resources. Comp. Political Stud. 2001, 34, 63-93. [CrossRef]

39. Baland, J.-M.; Platteau, J.-P. Halting Degradation of Natural Resources: Is There a Role for Rural Communities; Food \& Agriculture Org. Clarendon Press: Oxford, UK, 1996.

40. Davies, B.; Blackstock, K.; Brown, K.; Shannon, P. Challenges in Creating Local Agri-Environmental Cooperation Action Amongst Farmers and Other Stakeholders; The Macaulay Institute: Aberdeen, Scotland, 2004; pp. 1-131.

41. Dietz, T.; Ostrom, E.; Stern, P.C. The struggle to govern the commons. Science 2003, 302, 1907-1912. [CrossRef]

42. Hartanto, H.; Lorenzo, M.C.B.; Frio, A.L. Collective action and learning in developing a local monitoring system. Int. For. Rev. 2002, 4, 184-195. [CrossRef]

43. Topp-Jørgensen, E.; Poulsen, M.K.; Lund, J.F.; Massao, J.F. Community-based monitoring of natural resource use and forest quality in montane forests and miombo woodlands of Tanzania. Biodivers. Conserv. 2005, 14, 2653-2677. [CrossRef]

44. Danielsen, F.; Burgess, N.D.; Balmford, A. Monitoring matters: Examining the potential of locally-based approaches. Biodivers. Conserv. 2005, 14, 2507-2542. [CrossRef]

45. Eggert, H.; Ellegård, A. Fishery control and regulation compliance: A case for co-management in Swedish commercial fisheries. Mar. Policy 2003, 27, 525-533. [CrossRef]

46. Mosler, H.J.; Brucks, W.M. Integrating commons dilemma findings in a general dynamic model of cooperative behavior in resource crises. Eur. J. Soc. Psychol. 2003, 33, 119-133. [CrossRef]

47. Bicchieri, C. Covenants without swords: Group identity, norms, and communication in social dilemmas. Ration. Soc. 2002, 14, 192-228. [CrossRef]

48. Sally, D. Conversation and cooperation in social dilemmas: A meta-analysis of experiments from 1958 to 1992. Ration. Soc. 1995, 7, 58-92. [CrossRef]

49. Ostrom, E. A behavioral approach to the rational choice theory of collective action: Presidential address, American Political Science Association, 1997. Am. Political Sci. Rev. 1998, 92, 1-22. [CrossRef]

50. Balliet, D. Communication and cooperation in social dilemmas: A meta-analytic review. J. Confl. Resolut. 2010, 54, 39-57. [CrossRef]

51. Cieslik, K.J.; Leeuwis, C.; Dewulf, A.R.P.J.; Lie, R.; Werners, S.E.; van Wessel, M.; Feindt, P.; Struik, P.C. Addressing socio-ecological development challenges in the digital age: Exploring the potential of Environmental Virtual Observatories for Connective Action (EVOCA). Njas-Wagening. J. Life Sci. 2018, 86-87, 2-11. [CrossRef]

52. Asenso-Okyere, K.; Mekonnen, D.A. The importance of ICTs in the provision of information for improving agricultural productivity and rural incomes in Africa. Afr. Hum. Dev. Rep. Undp Spons. Res. Ser. 2012, 1, 1-32.

53. Asongu, S.A.; Le Roux, S. Enhancing ICT for inclusive human development in Sub-Saharan Africa. Technol. Forecast. Soc. Chang. 2017, 118, 44-54. [CrossRef]

54. Furuholt, B.; Matotay, E. The developmental contribution from mobile phones across the agricultural value chain in rural Africa. Electron. J. Inf. Syst. Dev. Ctries. 2011, 48, 1-16. [CrossRef]

55. Kaske, D.; Mvena, Z.S.K.; Sife, A.S. Mobile phone usage for accessing agricultural information in Southern Ethiopia. J. Agric. Food Inf. 2018, 19, 284-298. [CrossRef]

56. Corbin, J.; Anselm, S. Basics of Qualitative Research. Techniques and Procedures for Developing Grounded Theory; Sage Publications: Los Angeles, CA, USA, 2008.

57. Andersson, K.; Benavides, J.P.; León, R. Institutional diversity and local forest governance. Environ. Sci. Policy 2014, 36, 61-72. [CrossRef] 
58. Coleman, E.A.; Steed, B.C. Monitoring and sanctioning in the commons: An application to forestry. Ecol. Econ. 2009, 68, 2106-2113. [CrossRef]

59. Gibson, C.C.; Williams, J.T.; Ostrom, E. Local enforcement and better forests. World Dev. 2005, 33, $273-284$. [CrossRef]

60. Genin, S. Molecular traits controlling host range and adaptation to plants in Ralstonia solanacearum. New Phytol. 2010, 187, 920-928. [CrossRef] [PubMed]

61. Priou, S.; Salas, C.; De Mendiburu, F.; Aley, P.; Gutarra, L. Assessment of latent infection frequency in progeny tubers of advanced potatoclones resistant to bacterial wilt: A new selection criterion. Potato Res. 2001, 44, 359-373. [CrossRef]

62. Swanson, J.K.; Montes, L.; Mejia, L.; Allen, C. Detection of latent infections of Ralstonia solanacearum race 3 biovar 2 in geranium. Plant Dis. 2007, 91, 828-834. [CrossRef]

63. Trawick, P.B. Successfully governing the commons: Principles of social organization in an Andean irrigation system. Hum. Ecol. 2001, 29, 1-25. [CrossRef]

64. Colquitt, J.A.; Conlon, D.E.; Wesson, M.J.; Porter, C.O.; Ng, K.Y. Justice at the millennium: A meta-analytic review of 25 years of organizational justice research. J. Appl. Psychol. 2001, 86, 425-445. [CrossRef]

65. Gezelius, S.S. Food, money, and morals: Compliance among natural resource harvesters. Hum. Ecol. 2004, 32, 615-634. [CrossRef]

66. Tadesse, G.; Bahiigwa, G. Mobile phones and farmers' marketing decisions in Ethiopia. World Dev. 2015, 68, 296-307. [CrossRef]

67. Ethiopian Agricultural Transformation Agency (ATA) Annual Report 2013-2014: Transforming Agriculture in Ethiopia; ATA: Addis Ababa, Ethiopia, 2014.

68. Gorfu, D.; Woldegiorgis, G.; Kassa, B. Bacterial Wilt: An Emerging Threat to Ethiopian Potato Industry. In Seed Potato Tuber Production and Dissemination: Experiences, Challenges and Prospects, Proceedings of the National Workshop on Seed Potato Tuber Production and Dissemination, Bahir Dar, Ethiopia, 12-14 March 2012; Woldegiorgis, G., Berihun, B., Schultz, S., Eds.; EIAR: Addis Ababa, Ethiopia, 2013.

69. Buddenhagen, C.E.; Hernandez Nopsa, J.F.; Andersen, K.F.; Andrade-Piedra, J.; Forbes, G.A.; Kromann, P.; Thomas-Sharma, S.; Useche, P.; Garrett, K.A. Epidemic network analysis for mitigation of invasive pathogens in seed systems: Potato in Ecuador. Phytopathology 2017, 107, 1209-1218. [CrossRef]

70. Thomas-Sharma, S.; Abdurahman, A.; Ali, S.; Andrade-Piedra, J.; Bao, S.; Charkowski, A.; Crook, D.; Kadian, M.; Kromann, P.; Struik, P.C. Seed degeneration in potato: The need for an integrated seed health strategy to mitigate the problem in developing countries. Plant Pathol. 2016, 65, 3-16. [CrossRef]

71. Schulte-Geldermann, E. Tackling Low Potato Yields in Eastern Africa: An Overview of Constraints and Potential Strategies. In Seed Potato Tuber Production and Dissemination: Experiences, Challenges and Prospects, Proceedings of the National Workshop on Seed Potato Tuber Production and Dissemination, Bahir Dar, Ethiopia, 12-14 March 2012; Woldegiorgis, G., Berihun, B., Schultz, S., Eds.; EIAR: Addis Ababa, Ethiopia, 2013. 